\title{
Last of the Black Titans
}




\section{TRANSGRESSIONS: CULTURAL STUDIES AND EDUCATION}

\section{Series Editor}

Shirley R. Steinberg, University of Calgary; Director of Institute of Youth and Community Studies, University of the West of Scotland

\section{Founding Editor}

Joe L. Kincheloe (1950-2008) The Paulo and Nita Freire International Project for Critical Pedagogy

\section{Editorial Board}

Rochelle Brock, Indiana University Northwest, USA

Rhonda Hammer, UCLA, USA

Luis Huerta-Charles, New Mexico State University, USA

Christine Quail, McMaster University, Canada

Jackie Seidel, University of Calgary, Canada

Mark Vicars, Victoria University, Queensland, Australia

This book series is dedicated to the radical love and actions of Paulo Freire, Jesus "Pato" Gomez, and Joe L. Kincheloe. 


\section{TRANSGRESSIONS: CULTURAL STUDIES AND EDUCATION}

Cultural studies provides an analytical toolbox for both making sense of educational practice and extending the insights of educational professionals into their labors. In this context Transgressions: Cultural Studies and Education provides a collection of books in the domain that specify this assertion. Crafted for an audience of teachers, teacher educators, scholars and students of cultural studies and others interested in cultural studies and pedagogy, the series documents both the possibilities of and the controversies surrounding the intersection of cultural studies and education. The editors and the authors of this series do not assume that the interaction of cultural studies and education devalues other types of knowledge and analytical forms. Rather the intersection of these knowledge disciplines offers a rejuvenating, optimistic, and positive perspective on education and educational institutions. Some might describe its contribution as democratic, emancipatory, and transformative. The editors and authors maintain that cultural studies helps free educators from sterile, monolithic analyses that have for too long undermined efforts to think of educational practices by providing other words, new languages, and fresh metaphors. Operating in an interdisciplinary cosmos, Transgressions: Cultural Studies and Education is dedicated to exploring the ways cultural studies enhances the study and practice of education. With this in mind the series focuses in a non-exclusive way on popular culture as well as other dimensions of cultural studies including social theory, social justice and positionality, cultural dimensions of technological innovation, new media and media literacy, new forms of oppression emerging in an electronic hyperreality, and postcolonial global concerns. With these concerns in mind cultural studies scholars often argue that the realm of popular culture is the most powerful educational force in contemporary culture. Indeed, in the twenty-first century this pedagogical dynamic is sweeping through the entire world. Educators, they believe, must understand these emerging realities in order to gain an important voice in the pedagogical conversation.

Without an understanding of cultural pedagogy's (education that takes place outside of formal schooling) role in the shaping of individual identity - youth identity in particular - the role educators play in the lives of their students will continue to fade. Why do so many of our students feel that life is incomprehensible and devoid of meaning? What does it mean, teachers wonder, when young people are unable to describe their moods, their affective affiliation to the society around them. Meanings provided young people by mainstream institutions often do little to help them deal with their affective complexity, their difficulty negotiating the rift between meaning and affect. School knowledge and educational expectations seem as anachronistic as a ditto machine, not that learning ways of rational thoughtandmaking sense of the world are unimportant.

But school knowledge and educational expectations often have little to offer students about making sense of the way they feel, the way their affective lives are shaped. In no way do we argue that analysis of the production of youth in an electronic mediated world demands some "touchy-feely" educational superficiality. What is needed in this context is a rigorous analysis of the interrelationship between pedagogy, popular culture, meaning making, and youth subjectivity. In an era marked by youth depression, violence, and suicide such insights become extremely important, even life saving. Pessimism about the future is the common sense of many contemporary youth with its concomitant feeling that no one can make a difference. 
If affective production can be shaped to reflect these perspectives, then it can be reshaped to lay the groundwork for optimism, passionate commitment, and transformative educational and political activity. In these ways cultural studies adds a dimension to the work of education unfilled by any other sub-discipline. This is what Transgressions: Cultural Studies and Education seeks to produce - literature on these issues that makes a difference. It seeks to publish studies that help those who work with young people, those individuals involved in the disciplines that study children and youth, and young people themselves improve their lives in these bizarre times. 


\section{Last of the Black Titans}

The Role of Historically Black Colleges and Universities in the 21st Century

\section{Greg Wiggan}

University of North Carolina at Charlotte, USA

with Lakia Scott

Baylor University, USA

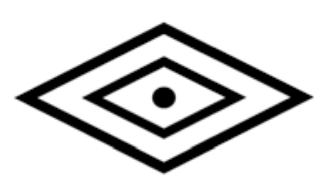

SENSE PUBLISHERS

ROTTERDAM/BOSTON/TAIPEI 
A C.I.P. record for this book is available from the Library of Congress.

ISBN: 978-94-6300-320-9 (paperback)

ISBN: 978-94-6300-321-6 (hardback)

ISBN: 978-94-6300-322-3 (e-book)

Published by: Sense Publishers,

P.O. Box 21858,

3001 AW Rotterdam,

The Netherlands

https://www.sensepublishers.com/

Printed on acid-free paper

All Rights Reserved ( 2015 Sense Publishers

No part of this work may be reproduced, stored in a retrieval system, or transmitted in any form or by any means, electronic, mechanical, photocopying, microfilming, recording or otherwise, without written permission from the Publisher, with the exception of any material supplied specifically for the purpose of being entered and executed on a computer system, for exclusive use by the purchaser of the work. 


\section{TABLE OF CONTENTS}

$\begin{array}{ll}\text { Acknowledgements } & \text { ix }\end{array}$

Introduction: Education under Siege, Last of the Black Titans xi

Chapter 1: Last of the Black Titans: Background on the Entry of Africans in the Americas

Contemporary Issues Facing HBCUs

Chapter 2: Historical and Social Context of Education for African Americans

Formation of Schools for African Americans 13

National Initiatives and HBCU Enrollment 18

HBCU Matriculation and Life Outcomes of Graduates 23

Chapter 3: In Their Voice: High School Students' Perceptions about HBCUs 25

Part I: Participants and Schools $\quad 26$

In Their Voice: What Is an HBCU? 27

In Their Voice: What Is a PWI? 30

In Their Voice: Institutional Differences between HBCUs and PWIs 30

Chapter 4: Where Are the Black Titans and What Can They Learn from Prospective Students? 45

HBCUs: Institutional Factors $\quad 45$

Racial Awareness $\quad 48$

Media Is Important 51

Returns on the Degree $\quad 53$

What Is Important to Prospective Students? 54

Recommendations $\quad 56$ 
TABLE OF CONTENTS

$\begin{array}{ll}\text { Appendices } & 61\end{array}$

$\begin{array}{ll}\text { Bibliography } & 67\end{array}$

$\begin{array}{ll}\text { About the Authors } & 77\end{array}$

$\begin{array}{ll}\text { Index } & 79\end{array}$

viii 


\section{ACKNOWLEDGEMENTS}

I wish to thank my very first teacher, Mrs. Lyons, the renowned educator in Sav-la-Mar, Westmoreland, Jamaica, and my last teacher, Dr. Asa Hilliard. I owe my deepest gratitude to these two educators who have had a profound impact on my growth and development. I also wish to thank my mother and father (and Baba Hilliard and Brother Robby), who taught me to be firm even when faced by institutional racism and prejudice. And to the 'Vicker,' elder ancestor Errol Peynado, and the queen mothers, Mama Scott and Mama "P," and to the late, Mr. Clinton Scarlett, who was the top librarian in Sav-la-Mar for at least three decades, blessed love. To Queen Makeda and Empress Izana, blessed love. "In loving memory of Dr. John Henrik Clarke." - Greg Wiggan. "To Dr. Clarke, Dr. Ben, and Dr. Hilliard"

I would like to recognize members of my family. To my husband and best friend, Chadwick Scott, I need to thank you immensely for allowing me to follow this dream. As we welcome Chadley into this world, I need to also thank my parents, Paul and Collette Jones, for their unwavering support and understanding of my academic pursuits. And I would like to especially thank Dr. Wiggan for all of his help and support. - Lakia Scott 



\title{
INTRODUCTION
}

\author{
Education under Siege, Last of the Black Titans
}

Historically Black Colleges and Universities (HBCUs) have-and continue to play a key role in the education of African Americans. In 1900, approximately 2,600 African Americans had postsecondary credentials, largely due to the efforts of public and private HBCUs (Jackson, 2001). Onehundred-and-ten years later, in the 2010-2011 academic year, the National Center for Education Statistics (NCES, 2013) reported that approximately 33,000 bachelor's degrees were conferred by HBCUs. In 2010, there were an estimated 4.6 million African Americans who had a college degree (JBHE, 2015). And in 2011, approximately 324,000 students were enrolled in the $100 \mathrm{HBCUs}$ across the U.S. (NCES, 2013). HBCUs account for between $9 \%$ and $10 \%$ of African American undergraduate student enrollment (NCES, 2013; Thurgood Marshall Fund, 2015), and they continue to represent a great legacy in the history of Black higher education.

Founded in 1837 through a generous donation by Richard Humphreys, who was a Quaker and philanthropist, the Institute for Colored Youth in Pennsylvania (later called Cheyney University), was the first HBCU in America (Cheyney University, 2015). This institution was monumental in the formation of Black higher education. Since that time, many historical and contemporary figures began their trek in post-secondary education at HBCUs. William Edward Burghardt Du Bois [W.E.B. Du Bois], sociologist, historian, Pan-Africanist and Civil Rights activist, was an HBCU alumnus. Du Bois graduated from Fisk University [Nashville, Tennessee] in 1888. He continued his education and received a second Bachelor's degree in History, graduate degree in Sociology, and Ph.D. in History from Harvard University in 1895 (Harvard University Press, n.d.), the year he became the first African American to receive a doctorate degree from the institution. Much of $\mathrm{Du}$ Bois' work examined the race, class, economics and political struggles of African Americans, issues he first became conscious of while studying at Fisk University. His collection of essays, books, and other writings are seminal works and invaluable contributions to our understanding of race relations.

Similarly, Langston Hughes, renowned poet, playwright and social activist, also graduated from an HBCU. Hughes graduated from Lincoln University [Chester County, Pennsylvania] in 1929. Through his poetry and other writings, he provides colorful portrayals of Black life in America 
during the early-to-mid-20th century (Lincoln University, n.d.). Hughes is recognized as one of the leaders of the Harlem Renaissance, which was a cultural movement that focused on African American artistic expressions and the struggle for equal rights (bio, 2015).

In 1930, future U.S. Supreme Court Justice Thurgood Marshall graduated from Lincoln University. It is also important to note that Kwame Nkrumah, the Pan-Africanist and former president of Ghana, was also a student at Lincoln University, where he completed a Bachelor's degree in Sociology in 1935. In pursuit of becoming a civil rights attorney, Thurgood Marshall entered law school at Howard University and graduated magna cum laude and first in his class in 1933 (Thurgood Marshall College Fund, 2012). Marshall was greatly involved in the National Association for the Advancement of Colored People's (NAACP) initiatives aimed at challenging Jim Crow legislation and discrimination against African Americans. He is best known for his involvement in the 1954 Supreme Court case Brown v. Board of Education, which declared public school segregation to be unconstitutional.

Additionally, Civil Rights Leader and Nobel Peace Laureate Dr. Martin Luther King, Jr. earned a Bachelor's degree in Sociology from Morehouse College in 1948 (Morehouse College, n.d.). It is worth noting that King, who was a child prodigy, was an early-admit and only fifteen years old when he began his education at Morehouse. By graduating from Morehouse, King was also continuing a family tradition that began with his grandfather, Dr. Adam Daniel Williams, in 1898. King's own sons, Martin (III) and Dexter, are also a part of the Morehouse legacy.

Toni Morrison, the highly acclaimed novelist and educator, is also an HBCU graduate. In 1953, Morrison graduated with a Bachelor of Arts degree in English from Howard University (Washington, D.C.). Morrison has received the Pulitzer Prize, the American Book Award, and the Nobel Prize for her work Beloved, which is still used in many U.S. schools today. Additionally, international figure, media proprietor, talk show host, actress, producer, philanthropist, and billionaire Oprah Winfrey, received her start at Tennessee State University as a Communications major, where she completed her degree in 1973.

Other notable African Americans who have graduated from HBCUs include Herman Cain [Morehouse, 1967], Jerry Rice [Mississippi Valley State University 1984], and Shelton "Spike" Lee [Morehouse College, 1979]. And more contemporarily, several prominent African Americans completed their education at HBCUs. Tom Joyner, radio host and founder of 
REACH Media, Inc., graduated from Tuskegee University with a Sociology degree in 1978. Similarly, Yolanda Adams, award-winning Gospel singer, radio show host, and actress graduated from Texas Southern University in 1983 with a degree in Radio/Television Communications. Pam Oliver, NBA and NFL sportscaster, graduated from Florida A\&M University in 1983 with a Bachelor's degree in Broadcast Journalism. Jacque Reid, popular television and radio personality, earned a Bachelor's degree in Print Journalism from Clark Atlanta University in 1989. And Stephen Anthony Smith, sports journalist and ESPN personality, received a degree in Mass Communications from Winston-Salem State University in 1991 (WinstonSalem State University, n.d.).

Anika Noni Rose, Tony Award-winning singer and actress, graduated from Florida A\&M University with a Bachelor's degree in Theatre in 1994 (FAMU, n.d.). Similarly, Taraji P. Henson, actress, singer, and Academy Award nominee began her college career at North Carolina A\&T State University, but soon after transferred to Howard University where she completed a degree in Fine Arts in 1995. Henson has shared stories of her son being racially profiled by police at University of Southern California (McGloster, 2015). As a result, she decided to enroll him at Howard University. In addition, Keshia Knight Pulliam, a young actress most popularly known for her role as "Rudy Huxtable" on "The Cosby Show," graduated from Spelman College with a Bachelor's degree in Sociology in 2001. In 2010, Pulliam founded Kamp Kizzy, a nonprofit organization for young girls. Additionally, in 2010, child prodigy Stephen R. Stafford II joined the legacy of Dr. Martin Luther King, Jr. by enrolling at Morehouse College at the age of 13, where he is a triple major in biology, mathematics and computer science. Stafford began taking courses at Morehouse when he was 11 years old.

In spite of HBCUs' long and decorated history of educating African Americans, their future remains uncertain. More recently, schools like St. Augustine's University and South Carolina State University have been struggling to stay open amidst accreditation and financial challenges. At Elizabeth City State University in North Carolina, the enrollment has decreased by $27 \%$. Additionally, Shaw University has more than 20 million dollars in debt (Chambers, 2015) and Barber-Scotia College lost its accreditation in 2004. Over the last 80 years, several HBCUs have closed, these closings include: Daniel Payne College [1889-1977], Friendship College [1891-1981], Guadalupe College [1884-1936], Kittrell College [1886-1975], Leland College [1870-1960], Mississippi Industrial College [1905-1982)], Western University (Kansas) [1865-1943], Prentiss Institute 
INTRODUCTION

[1907-1989], Bishop College [1881-1988], Natchez Junior College [1884-1989], Mary Holmes College [1892-2004], and South Carolina State University [on probationary status and proposed to temporarily close until 2017]. Schools like Morris Brown College, Howard, Clarke Atlanta, Fisk, Cheyney, Tennessee State, and Wilberforce Universities, among others, continue to face accreditation and or financial struggles.

These institutions are faced with contemporary challenges that include: declining Black student enrollment, financial instability, accreditation sanctions, and increasing speculations concerning the value of an $\mathrm{HBCU}$ degree in the 21 st century. Additionally, in consideration of the fact that the mission of HBCUs are changing in order to accommodate greater racial diversity, the need to sustain federal and state funding has had an impact on the enrollment of these institutions. Enrollment trends over the 20th - and now 21 st century, are indicative of how integration has both positively and negatively impacted HBCUs. Notwithstanding the social, political and economic changes in the American landscape, HBCUs continue to play an important role in African American higher education attainment (NCES, 2012), and they are some of the leading producers of Black science, technology, engineering and mathematics graduates (Upton \& Tanenbaum, 2014). In this sense, these institutions are the titans or giants of Black higher education. However, because of the gradual decline in Black enrollment at these institutions, there is a need to more deeply examine the relevance of these schools in the 21 st century.

It is in this light that this book explores the historical and contemporary role of HBCUs in the education of African Americans. While this is not intended to be an exhaustive treatment on the topic, the book examines how HBCUs have served - and continue to serve as a force in Black higher education. The book presents a case study of African American high school students' perceptions about attending an HBCU. Since these are the prospective students who are most likely to attend a Black institution of higher education, we explore the following research question: What are the perceptions of African American college-bound students on attending a Historically Black College or University?

In the context of this book, the following terms are operationalized.

\section{HISTORICALLY BLACK COLLEGE OR UNIVERSITY (HBCU)}

HBCUs are degree-granting institutions that were established in the 1800 s and prior to 1964 , with the principal mission of providing educational access 
and opportunities for African Americans. While HBCUs have traditionally and contemporarily served mainly African Americans, enrollment is open to all students regardless of their race or ethnicity. These schools are categorized as: public 2- and 4-year colleges/universities, private 4-year colleges/universities, and land-grant institutions. There are approximately 100 HBCUs [public and private] across the nation that confer associates, bachelors, and advanced-level degrees.

\section{PREDOMINATELY WHITE INSTITUTION (PWI)}

A predominantly White institution (PWI) is a postsecondary college or university with White students accounting for $50 \%$ or more of the student body. These institutions are considered historically White and are most commonly rooted with patterns and traditions of Western Europe.

\section{AFRICAN AMERICANS/BLACKS}

An African American is someone who is of African descent which can include being born in the U.S., but having African ancestral lineage. Additionally, this term is also inclusive of immigrant born Blacks, that is, people who are of African descent and now reside in - or outside of continental Africa. In this book, the term African Americans is used interchangeably with Blacks. Due to the historical and contemporary nature of the book's topic, we do not differentiate between the two terms.

In chapter 1, we provide a background on the pre-colonial entry of Africans into the Americas, as well as African educational traditions, and the struggles for education during the period of enslavement in North America. In the second chapter, we discuss the social, historical and contemporary context that pertains to the development of Black education and the formation of HBCUs as a framework for our study. In the third chapter, we introduce our study on African American college-bound students' perceptions about attending an HBCU. And in the final chapter, we discuss our findings and provide recommendations regarding the future of HBCUs. 